\title{
Synthesis, Characterization and Antimicrobial Activity of Mixed Transition Metal Complexes of Salicylic Acid with 1, 10-Phenanthroline
}

\section{${ }^{* 1}$ AMUDAT LAWAL; ${ }^{2}$ ADEOLU S. SHODEINDE; ${ }^{3}$ SALIU A. AMOLEGBE; ${ }^{1}$ SUNDAY E. ELAIGWU; ${ }^{4}$ MUSLIMAT T.YUNUS-ISSA}

\author{
${ }^{1}$ Department of Chemistry, University of Ilorin, Ilorin, Kwara State, Nigeria \\ ${ }^{2}$ Department of Industrial Chemistry, University of Ilorin, Ilorin, Kwara State, Nigeria \\ ${ }^{3}$ Department of Chemistry, Federal University of Agriculture, Abeokuta, Ogun State, Nigeria \\ ${ }^{4}$ School of Science, Federal College of Education, Osiele, Abeokuta, Ogun State, Nigeria. \\ *Correspondence author: amudat1112@gmail.com Tel +2348035850696
}

\begin{abstract}
A new series of $\mathrm{Mn}(\mathrm{II}), \mathrm{Fe}(\mathrm{II}), \mathrm{Co}(\mathrm{II}), \mathrm{Cu}(\mathrm{II})$ and $\mathrm{Zn}(\mathrm{II})$ mixed ligands-metal complexes derived from salicylic acid (SA) and 1,10-phenanthroline (PHEN) have been synthesized and characterized by spectroscopic studies. The coordination of the two ligands towards central metal ions has been proposed in the light of elemental analysis, IR, UV-vis spectroscopic studies. The results of the physical and spectroscopic data confirmed that the ligands are chelating agents. In 1, 10-phenanthroline, coordination occurred through the two pyridinic nitrogen groups, while in the salicylic acid coordination occurred through the oxygen of the hydroxyl and the carboxylic groups. All the complexes synthesized were of octahedral geometry.Antimicrobial activity of the mixed ligands metal complexes and the free ligands were carried out against the bacterial Escherichia coli, staphylococcus aureus, klebsiella pneumonia, pseudomonas aeruginosa and the fungi candida spp. The mixed ligands metal complexes showed higher activities when compared to the free ligands of salicylic acid but were less active than the free 1,10-phenanthroline ligand. The complexes of $\mathrm{Cu}$ (II) showed the highest antimicrobial activity while the $\mathrm{Fe}(\mathrm{II})$ complex showed the least activity against the bacterial and fungi organisms. (C) JASEM
\end{abstract}

\section{https://dx.doi.org/10.4314/jasem.v21i3.18}

Key Words: 1,10-phenanthroline, Salicylic acid, Mixed ligands-metal complexes, Transition metal, Spectroscopy, Antimicrobial.

Transition metal complexes are cationic, neutral or anionic species in which a transition metal is coordinated by ligands (Cox, 2005). Transition metal ions are known to play very important roles in biological processes in the human body. For example, $\mathrm{Zn}$ (II) and $\mathrm{Cu}$ (II) ions are the second and third most abundant transition metals in humans (Kaim ,et al., (1996) and Xiao-Ming, et al., (1996). They are found either at the active sites or as structural components of a good number of enzymes. Cobalt is present in vitamin B12, a co-enzyme that plays significant roles in some biochemical processes. There are numerous lists of transition metals which are effective therapeutic agents especially when coordinated to a ligand to form metal complexes. A list of metal containing compounds used in chemotherapy for treatment of diseases include platinum (anticancer), silver (antimicrobial), gold (antiarthritic), bismuth (antiulcer), antimony (antiprotozoal), vanadium (antidiabetic) and iron (antimalaria) (Huang, et al. (2005).Nitrogen containing chiral ligands have found wide applications in chemotherapy and asymmetric catalysis. Among them 1, 10 -phenanthroline is particularly attractive for its ability to coordinate several metal ions, and thus to generate different catalytic species involved in a great variety of reactions. (Puglisi,et al., 2003). The ligand (1, $10-$ phenanthroline) is a strong field bidentate ligand that forms very stable chelates with many first row transition metals (Lee, (1991). Salicylic acid is biosynthesized from the amino acid phenylalanine and can be produced by sodium salicylate (Diarmiud, (2005) and Philip, (2000). In modern medicine, salicylic acid and its derivatives are used as constituents of some rubefacient products, for example, methyl salicylate is used as a liniment to soothe joint and muscle pain, choline salicylate is used typically to relieve the pain of aphthous ulcers (Wecker and Laubert, (2000).

A lot of metal complexes of 1,10-phenanthroline, salicylic acid have been reported in combination with other ligands, very few reports have appeared in literatures for the mixed ligands-metal complexes of 1,10-phenanthroline and salicylic acid. Thus, this article reports the synthesis, characterization and 
antimicrobial activity of some mixed metal complexes of 1,10-phenanthroline and salicylic acid.

\section{MATERIALS AND METHOD}

Metal salts used for these syntheses were obtained from British Drug House Chemical Limited (BDH), England and were used as supplied. 1, 10Phenanthroline was obtained from KEM Light laboratories PVT. LTD, India and salicylic acid used was sourced from Emzor Pharmaceuticals, Lagos. Cultures of the micro-organisms used were obtained from Department of Microbiology, University of Ilorin.

Synthesis of mixed ligands-metal complexes: The method described by Agwara et al., (2010) was employed in the synthesis of the mixed ligand-metal complexes of 1, 10-phenanthroline with salicylic acid. The metal salt $1 \mathrm{mmol}\left(\mathrm{M}=\mathrm{MnCl}_{2} \cdot 4 \mathrm{H}_{2} \mathrm{O}\right.$, $\mathrm{CuCl}_{2} \cdot 2 \mathrm{H}_{2} \mathrm{O}, \mathrm{CoCl}_{2} \cdot 6 \mathrm{H}_{2} \mathrm{O}, \mathrm{FeCl}_{2} \cdot 4 \mathrm{H}_{2} \mathrm{O}$ and $\mathrm{ZnCl}_{2}$ ) were dissolved in $10 \mathrm{ml}$ of appropriate solvent and stirred at room temperature. $2 \mathrm{mmol}$ each of the ligands 1,10-phenanthroline (PHEN) (0.396 g) and salicylic acid (SA) $(0.276 \mathrm{~g})$ were dissolved in $10 \mathrm{ml}$ of ethanol and added in drops to the already stirring metal salt solution at room temperature. After the addition of the ligands in drops, the solution was further stirred for one hour. The colour change and $\mathrm{pH}$ were recorded. The solution obtained was kept in a beaker covered with perforated aluminum foil in a quiet out of the way location for 21 days for the evaporation of the solvent. The crystals formed were washed with a mixture of ethanol and distilled water and dried in a desiccator over silica gel.

The proposed equation for the reaction:

$\mathrm{MX}_{2} \cdot \mathrm{nH}_{2} \mathrm{O}+\mathrm{SA}+\mathrm{PHEN} \longrightarrow[\mathrm{M}(\mathrm{SA})$ $\left.(\mathrm{PHEN})\left(\mathrm{H}_{2} \mathrm{O}\right)_{2}\right]+\mathrm{X}_{2}$ $\mathrm{M}=$ metal ion, $\mathrm{X}=$ Halide, $\mathrm{SA}=$ salicylic acid, PHEN = 1,10-phenanthroline

Characterization of the complexes: The infrared spectra of the ligands and complexes were recorded in $\mathrm{KBr}$ pellets in the range $\left(400-400 \mathrm{~cm}^{-1}\right)$ on IR Affinity-1S FT-IR spectrophotometer. The electronic spectra were recorded on Aquamate scientific spectrophotometer model V 4.60. The elemental analysis was recorded on Perkin-Elmer CHN Analyzer 2400 series II. Conductivity measurements were carried out HNNA EC 214 conductivity meter with a cell constant of 0.83 .

Antimicrobial studies: The antimicrobial activities of the free ligands and the mixed ligand-metal complexes were determined according to the method described by Adediji et al.,(2009). The bacterial species used for this study are Escherichia coli, Pseudomonas aeruginosa, Staphylococcus aureus, Klebsiella spp., and the fungi Candida spp.

\section{RESULTS AND DISCUSSION}

The results of the physical properties of the ligands and their complexes are presented in table 1

Table 1: Some physical properties of 1,10-phenanthroline, salicylic acid and their complexes

\begin{tabular}{llllc}
\hline Ligangs/ complexes & State & Colour & Mpt $\left({ }^{0} \mathrm{C}\right)$ & Conductivity $\left(\mu \mathrm{Scm}^{2}\right)$ \\
& & & & \\
\hline 1,10 -phenanthroline & Crystalline & White & 117 & \\
Salicylic acid & Powdery & White & 158.6 & \\
{$\left[\mathrm{Mn}(\mathrm{SA})(\mathrm{PHEN})\left(\mathrm{H}_{2} \mathrm{O}\right)_{2}\right] \cdot \mathrm{Cl}_{2}$} & Crystalline & Yellow & $248-250$ & 16.6 \\
{$\left[\mathrm{Cu}(\mathrm{SA})(\mathrm{PHEN})\left(\mathrm{H}_{2} \mathrm{O}\right)_{2}\right] \cdot \mathrm{Cl}_{2}$} & Crystalline & Green & $150-152$ & 57.8 \\
{$\left[\mathrm{Co}(\mathrm{SA})(\mathrm{PHEN})\left(\mathrm{H}_{2} \mathrm{O}\right)_{2}\right] \cdot \mathrm{Cl}_{2}$} & Crystalline & Red & $238($ decompose $)$ & 36 \\
{$\left[\mathrm{Fe}(\mathrm{SA})(\mathrm{PHEN})\left(\mathrm{H}_{2} \mathrm{O}\right)_{2}\right] \cdot \mathrm{Cl}_{2}$} & Powdery & Red & $350-352$ & 52.6 \\
{$\left[\mathrm{Zn}(\mathrm{SA})(\mathrm{PHEN})\left(\mathrm{H}_{2} \mathrm{O}\right)_{2}\right] \cdot \mathrm{Cl}_{2}$} & Powdery & Pink & 300 (decompose) & 5.8 \\
\hline
\end{tabular}

The complexes were only soluble in dimethyl sulfoxide except for $\left[\mathrm{Cu}(\mathrm{SA})(\mathrm{PHEN})\left(\mathrm{H}_{2} \mathrm{O}\right)_{2}\right] . \mathrm{Cl}_{2}$ which was slightly soluble in hot distilled water and ethanol. The complexes melt above $248{ }^{0} \mathrm{C}$, with the exception of $\left[\mathrm{Cu}(\mathrm{SA})(\mathrm{PHEN})\left(\mathrm{H}_{2} \mathrm{O}\right)_{2}\right] \cdot \mathrm{Cl}_{2}$ which melts at $152{ }^{0} \mathrm{C}$ and the complexes of $\left[\mathrm{Co}(\mathrm{SA})(\mathrm{PHEN})\left(\mathrm{H}_{2} \mathrm{O}\right)_{2}\right] \cdot \mathrm{Cl}{ }_{2}$ and $\left[\mathrm{Zn}(\mathrm{SA})(\mathrm{PHEN})\left(\mathrm{H}_{2} \mathrm{O}\right)_{2}\right] \cdot \mathrm{Cl}_{2}$ which decomposed at 238 and $300{ }^{0} \mathrm{C}$ respectively. (Mohamed et al., (2014) 
The results of the elemental analysis of some of the complexes are presented in table 2 below

Table 2: The results of the elemental analysis

\begin{tabular}{lllll}
\hline \multirow{2}{*}{ Complexes } & \multicolumn{4}{l}{$\%$ Calculated $(\%$ Found $)$} \\
& $\% \mathrm{C}$ & $\% \mathrm{H}$ & $\% \mathrm{~N}$ & $\% \mathrm{O}$ \\
\hline$\left[\mathrm{Mn}(\mathrm{SA})(\mathrm{PHEN})\left(\mathrm{H}_{2} \mathrm{O}\right)_{2}\right] \cdot \mathrm{Cl}_{2}$ & 47.61 & 3.55 & 5.85 & 16.70 \\
& $(47.64)$ & $(3.56)$ & $(5.85)$ & $(16.72)$ \\
& 46.77 & 3.49 & 5.74 & 16.41 \\
{$\left[\mathrm{Cu}(\mathrm{SA})(\mathrm{PHEN})\left(\mathrm{H}_{2} \mathrm{O}\right)_{2}\right] \cdot \mathrm{Cl}_{2}$} & $(46.80)$ & $(3.51)$ & $(5.76)$ & $(16.43)$ \\
& 47.63 & 3.37 & 5.85 & 16.71 \\
{$\left[\mathrm{Fe}(\mathrm{SA})(\mathrm{PHEN})\left(\mathrm{H}_{2} \mathrm{O}\right)_{2}\right] \cdot \mathrm{Cl}_{2}$} & $(47.65)$ & $(3.38)$ & $(5.87)$ & $(16.73)$ \\
& & & & \\
\hline
\end{tabular}

The elemental analysis results for carbon, hydrogen, nitrogen and oxygen found were very close to the calculated values which are an indication of the purity of the complexes and these also indicated that the ligands coordinated to the central metal ion in the ratio $1: 1: 1$ that is $\mathrm{L}_{1}-\mathrm{M}-\mathrm{L}_{2}$. Where $\mathrm{L}_{1}=$ Ligand $\mathrm{M}=\mathrm{Metal}$ salts and $\mathrm{L}_{2}=$ Ligand.

The results of the electronic spectra of the ligands and their complexes are presented in table 3 below

Table3: The electronic Spectra for the free ligands and its complexes.

\begin{tabular}{lccc}
\hline Ligands / complexes & $\begin{array}{c}\text { Wavelength } \\
(\mathrm{nm})\end{array}$ & $\begin{array}{c}\text { Energies } \\
\left(\mathrm{cm}^{-1}\right)\end{array}$ & $\begin{array}{c}\text { Tentative } \\
\text { assignment }\end{array}$ \\
\hline 1,10-phenanthroline & 331 & 30211 & $\mathrm{n} \rightarrow \pi^{*}$ \\
Salicylic Acid & 317 & 31546 & $\mathrm{n} \rightarrow \pi^{*}$ \\
{$\left[\mathrm{Mn}(\mathrm{SA})(\mathrm{PHEN})\left(\mathrm{H}_{2} \mathrm{O}\right)_{2}\right] \cdot \mathrm{Cl}_{2}$} & 311 & 32154 & $\mathrm{MLCT}$ \\
{$\left[\mathrm{Cu}(\mathrm{SA})(\mathrm{PHEN})\left(\mathrm{H}_{2} \mathrm{O}\right)_{2}\right] \cdot \mathrm{Cl}_{2}$} & 360 & 27778 & ${ }^{2} \mathrm{E}_{\mathrm{g}} \rightarrow{ }^{2} \mathrm{~T}_{2 \mathrm{~g}}$ \\
{$\left[\mathrm{Co}(\mathrm{SA})(\mathrm{PHEN})\left(\mathrm{H}_{2} \mathrm{O}\right)_{2}\right] \cdot \mathrm{Cl}_{2}$} & 312 & 32051 & $\mathrm{MLCT}$ \\
{$\left[\mathrm{Fe}(\mathrm{SA})(\mathrm{PHEN})\left(\mathrm{H}_{2} \mathrm{O}\right)_{2}\right] \cdot \mathrm{Cl}_{2}$} & 557 & 17953 & ${ }^{5} \mathrm{~T}_{2 \mathrm{~g}} \rightarrow{ }^{5} \mathrm{E}_{\mathrm{g} 2}$, \\
{$\left[\mathrm{Zn}(\mathrm{SA})(\mathrm{PHEN})\left(\mathrm{H}_{2} \mathrm{O}\right)_{2}\right] \cdot \mathrm{Cl}_{2}$} & 299 & 33444 & $\mathrm{n} \rightarrow \pi^{*}$ \\
\hline
\end{tabular}

The electronic spectra data of the ligands and its mixed complexes, which were recorded at room temperature in dimethyl sulfoxide (DMSO) solution at (200-800 $\mathrm{nm})$. Broad absorption bands were observed at $317 \mathrm{~nm}$ (Salicylic acid), and $331 \mathrm{~nm}$ (1,10-Phenantholine) and assigned to transitions of ( $\mathrm{n}$ $\left.\rightarrow \pi^{*}\right)$ as a result of intra ligand charge transfer (ILCT) of the aromatic chromophore (Lever, (1968). Band of $312 \mathrm{~nm}$ was observed in $\left[\mathrm{Co}(\mathrm{SA})(\mathrm{PHEN})\left(\mathrm{H}_{2} \mathrm{O}\right)_{2}\right] \cdot \mathrm{Cl}_{2}$ complex and assigned to transition of MLCT, which is a feature in octahedral stereochemistry. The $\left[\mathrm{Cu}(\mathrm{SA})(\mathrm{PHEN})\left(\mathrm{H}_{2} \mathrm{O}\right)_{2}\right] \cdot \mathrm{Cl}_{2}$ complex show band $360 \mathrm{~nm}$ and assigned to ${ }^{2} \mathrm{E}_{\mathrm{g}} \rightarrow{ }^{2} \mathrm{~T}_{2 \mathrm{~g}}$ transition. The band of $311 \mathrm{~nm}$ for $\left[\mathrm{Mn}(\mathrm{SA})(\mathrm{PHEN})\left(\mathrm{H}_{2} \mathrm{O}\right)_{2}\right] \cdot \mathrm{Cl}_{2}$ is assigned to MLCT transitions, this band is forbidden and diffused due to its $\mathrm{d}^{5}$ configuration, electrons occupying both lower and upper orbitals (Lever, (1968). The $\left[\mathrm{Fe}(\mathrm{SA})(\mathrm{PHEN})\left(\mathrm{H}_{2} \mathrm{O}\right)_{2}\right] \cdot \mathrm{Cl}_{2}$ shows band at $557 \mathrm{~nm}$, assignable to ${ }^{5} \mathrm{~T}_{2 \mathrm{~g}} \rightarrow{ }^{5} \mathrm{E}_{\mathrm{g}}$, which is also a feature of octahedral geometry (William, 1991). $\left[\mathrm{Zn}(\mathrm{SA})(\mathrm{PHEN})\left(\mathrm{H}_{2} \mathrm{O}\right)_{2}\right] \cdot \mathrm{Cl}_{2}$ complexes displayed band at $299 \mathrm{~nm}$, due to intra-ligand charge transfer and the ground term symbol shows no splitting with a $\mathrm{d}^{10}$ configuration and completely filled d-orbitals. Due to the weak absorption bands intensity, an octahedral geometry was proposed with possible assignment of $n \rightarrow \pi^{*}$.

Results of selected infrared spectra of 1,10phenanthroline, salicylic acid (SA), and their metal complexes are presented in table 4 below 
Table 4: The characteristic infrared data $\left(\mathrm{cm}^{-1}\right)$ of 1,10-phenanthroline, salicylic acid (SA), their metal

\begin{tabular}{lllllll}
\hline Ligands/Complexes & $v(\mathrm{C}=\mathrm{N})$ & $v(\mathrm{O}-\mathrm{H})$ & $v(\mathrm{OCO})_{\text {asym }}$ & $v(0 \mathrm{C} 0)_{\text {sym }}$ & $v(\mathrm{M}-\mathrm{N})$ & $v(\mathrm{M}-\mathrm{O})$ \\
\hline Salicylic acid & - & 3421 & 1691 & 1460 & \\
1,10 -phenanthroline & 1630 & - & & & & \\
{$\left[\mathrm{Mn}(\mathrm{SA})(\mathrm{PHEN})\left(\mathrm{H}_{2} \mathrm{O}\right)_{2}\right] \cdot \mathrm{Cl}_{2}$} & - & -3059 & 1664 & 1487 & 468 & 542 \\
{$\left[\mathrm{Cu}(\mathrm{SA})(\mathrm{PHEN})\left(\mathrm{H}_{2} \mathrm{O}\right)_{2}\right] \cdot \mathrm{Cl}_{2}$} & 1606 & 3059 & 1664 & 1425 & 426 & 534 \\
{$\left[\mathrm{Co}(\mathrm{SA})(\mathrm{PHEN})\left(\mathrm{H}_{2} \mathrm{O}\right)_{2}\right] \cdot \mathrm{Cl}_{2}$} & 1514 & 3051 & 1656 & 1423 & 422 & 536 \\
{$\left[\mathrm{Fe}(\mathrm{SA})(\mathrm{PHEN})\left(\mathrm{H}_{2} \mathrm{O}\right)_{2}\right] \cdot \mathrm{Cl}_{2}$} & - & 3406 & 1644 & 1419 & 451 & 539 \\
{$\left[\mathrm{Zn}(\mathrm{SA})(\mathrm{PHEN})\left(\mathrm{H}_{2} \mathrm{O}\right)_{2}\right] \cdot \mathrm{Cl}_{2}$} & 1499 & 3406 & 1640 & 1427 & 401 & 615 \\
\hline
\end{tabular}

In order to get further information about the coordination behavior of the ligand salicylic acid (SA) and 1,10-phenanthroline (phen) with metal ions, comparison of the infrared spectra of the free ligands and their complexes were made. The broad band at $3421 \mathrm{~cm}^{-1}$ in the spectrum of the free ligand (SA) was assigned to the $v(\mathrm{O}-\mathrm{H})$ group, while another strong absorption band at $1691 \mathrm{~cm}^{-1}$ could be explained as $v(\mathrm{OCO})$ asym where the $\mathrm{v}(\mathrm{OCO})$ sym was noticed at $1460 \mathrm{~cm}^{-1}$ (Sliverstein ,et al., (2005). The spectrum of free 1,10-phenanthroline (phen) showed band that was observed at $1630 \mathrm{~cm}^{-1}$ assigned to $v(\mathrm{C}=\mathrm{N})($ Greenwood et al., (2011). The spectra of the complexes exhibited marked differences in the absorption band belonging to the stretching vibration of $v(\mathrm{O}-\mathrm{H})$ of hydroxyl group which has been found in the range of $3051-3361.93 \mathrm{~cm}^{-1}$ to undergo a hypsochromic shift suggesting the possibility of (SA) coordination through the oxygen atom at the hydroxyl group, absorption assigned for $v(\mathrm{OCO})$ sym was noticed at the range $1421.54 \mathrm{~cm}^{-1}-1487 \mathrm{~cm}^{-1}$ while the band caused by v(OCO) asym appeared between $1620-1664 \mathrm{~cm}^{-1}$ also undergo hypsochromic shift which indicates the coordination of the carboxylic group to the central metal ion. The stretching vibration band for $v(\mathrm{C}=\mathrm{N})$ were observed in the range of $1512-1606 \mathrm{~cm}^{-1}$ also by undergoing hypsochromic shift which means that the nitrogen atom of 1,10-phenanthroline was involved in coordination (Triathi and Aarti (2014). Metalnitrogen and M-Oxygen bands were further confirmed as coordination sites by the presence of the stretching vibrations of $\mathrm{v}(\mathrm{M}-\mathrm{N})$ and $\mathrm{v}(\mathrm{M}-\mathrm{O})$ around $418 \mathrm{~cm}^{-1}-468.70 \mathrm{~cm}^{-1}$ and $511.14 \mathrm{~cm}^{-1}-545.21 \mathrm{~cm}^{-1}$ respectively. Furthermore, the bands of coordinated water observed at the range of $842 \mathrm{~cm}^{-1}-869 \mathrm{~cm}^{-1}$ support the proof that there is the presence of water in the lattice of the complexes (Dilip, et al., (2012), El-Ghamry et al., (2013) and Shebl et al., 2010).

Due to limited availability of other spectroscopic techniques such as X-ray crystallography, NMR and mass spectroscopy and on the basis of the analytical data obtained such as melting point, solubility test, conductance, elemental analysis and the spectroscopic data obtained from UV-Visible, IR, and the following octahedral geometry structures have been proposed for the new complexes.

Proposed structure

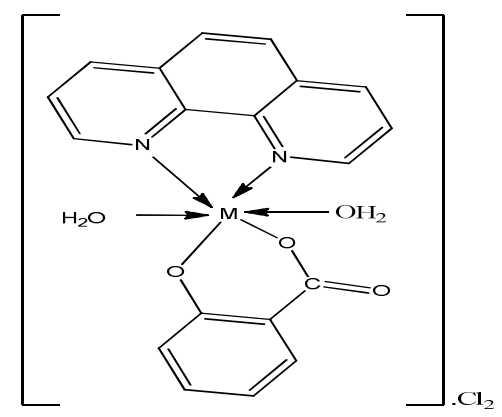

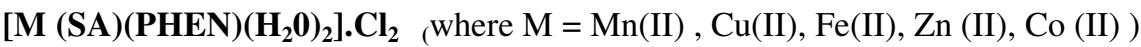

Antimicrobial activity studies of the free ligands and some their complexes are presented in table 5 below. 
Table 5: comparison of the antimicrobial activity of the free ligands and some of their complexes

\begin{tabular}{|c|c|c|c|c|c|c|c|c|c|c|}
\hline \multirow[t]{3}{*}{ Ligands/complexes } & E. coll & & $P . a$ & & $S a$ & & $K . \mathrm{spp}$ & \multirow[b]{3}{*}{500} & \multicolumn{2}{|c|}{ Can.spp. } \\
\hline & \multicolumn{6}{|c|}{ Concentration of ligands and mixed complexes (ppm) } & \multirow[b]{2}{*}{200} & & & \\
\hline & 200 & 500 & 200 & 500 & 200 & 500 & & & 200 & 500 \\
\hline 1,10-phenanthroline & 1.5 & 1.9 & 0.9 & 1.6 & 1.3 & 1.9 & 3.2 & 3.8 & 3.3 & 3.9 \\
\hline Salicylic Acid & 0 & 0 & 0 & 0 & 0 & 0.3 & 0 & 0 & 0 & 0 \\
\hline$\left[\mathrm{Mn}(\mathrm{SA})(\mathrm{PHEN})\left(\mathrm{H}_{2} \mathrm{O}\right)\right] \cdot \mathrm{Cl}_{2}$ & 0 & 0.8 & 0 & 0.6 & 0 & 0.8 & 0 & 1.8 & 0 & 0.8 \\
\hline$\left[\mathrm{Cu}(\mathrm{SA})(\mathrm{PHEN})\left(\mathrm{H}_{2} \mathrm{O}\right)\right] \cdot \mathrm{Cl}_{2}$ & 1.1 & 2.5 & 0 & 0.5 & 1.2 & 1.4 & 1.7 & 2.3 & 0 & 0.9 \\
\hline$\left[\mathrm{Fe}(\mathrm{SA})(\mathrm{PHEN})\left(\mathrm{H}_{2} \mathrm{O}\right)\right] \cdot \mathrm{Cl}_{2}$ & 0 & 0 & 0 & 0 & 0 & 0.3 & 0 & 0.8 & 0 & 0.5 \\
\hline
\end{tabular}

The results of the antimicrobial activity of the free ligands compared to their mixed complexes showed that the free 1,10-Phenanthroline was most active against the five organisms; Escherichia coli, (E. coli) Pseudomonas aeruginosa (P.a), Staphylococcus aureus (S. a), Klebsiellaspp.( $\quad \boldsymbol{K}$. $\quad$ spp.) and Candidaspp.(Can. spp.) on which the tests were carried out has compared to the free salicylic acid ligand that showed no activity against the organisms at $200 \mathrm{ppm}$ and only minute activity was recorded when the concentration of the solution was increased to 500 ppm (Agwara et al., 2010).

The mixed ligand-metal complexes showed improved antimicrobial activity mainly due to the presence of the metal which coordinates the individual ligands together (Agwara et al., (2012).

The complexes showed identical activity when both concentrations (200 ppm and $500 \mathrm{ppm}$ ) used for the test were compared which is an indication that the activity of the complexes is not solely dependent on the concentration of the solution but also on the inherent activity of the complexes. The complexes of $\mathrm{Fe}(\mathrm{II})$ showed no activity against the test organisms at the $200 \mathrm{ppm}$, likewise at $500 \mathrm{ppm}$ the activity was almost insignificant compared to the other complexes.

The complex of $\left[\mathrm{Mn}(\mathrm{SA})(\mathrm{PHEN})\left(\mathrm{H}_{2} \mathrm{O}\right)_{2}\right] \cdot \mathrm{Cl}_{2}$ showed no activity at $200 \mathrm{ppm}$ but showed improved activity at $500 \mathrm{ppm}$ on the test organisms. The order of activity of the complexes starting from the least to the most active is $\left[\mathrm{Fe}(\mathrm{SA})(\mathrm{PHEN}) \quad\left(\mathrm{H}_{2} \mathrm{O}\right)_{2}\right] \cdot \mathrm{Cl}_{2}<$ $\left[\mathrm{Mn}(\mathrm{SA})(\mathrm{PHEN})\left(\mathrm{H}_{2} \mathrm{O}\right)_{2}\right] . \mathrm{Cl}_{2}<$

$\left[\mathrm{Cu}(\mathrm{SA})(\mathrm{PHEN})\left(\mathrm{H}_{2} \mathrm{O}\right)_{2}\right] . \mathrm{Cl}_{2}$ (Agwara et al., (2010) and Agwara et al., (2013).

Conclusion: Mixed ligands metal complexes of 1,10phenanthroline salicylic acid and were synthesized. The complexes were characterized using melting point, conductivity measurement, elemental analysis, UV-Visible and IR spectroscopy. The results of the physical and spectroscopic data confirmed that the ligands are chelating agents. In 1,10-phenanthroline, coordination occurred through the two pyridinic nitrogen groups, while in the salicylic acid coordinated through the oxygen of the hydroxyl and the carboxylic groups. All the complexes synthesized were of octahedral geometry. The ligands and their respective complexes were screened against both bacterial and fungi species as a potential antimicrobial agents. The antimicrobial activities of the complexes were found to be greater than those of the free salicylic acid ligand, but the free 1,10phenanthroline exhibited antimicrobial activity which is greater than those of the free salicylic acid ligandand the mixed ligand-metal complexes.

\section{REFERENCES}

Adediji, J. F., Obaleye, J.A., Adeniran, G.O., Adebayo M. A., Olayinka E. T. (2009) "Fe(III) complex of mefloquine hydrochloride: Synthesis, antimicrobial and toxicological activities".African journal of biotechnology. 8 (21): 5891-5896.

Agwara, M.O., Ndosiri, N.B., Paboudam, A.G., Ndifon, P.T., Yufanyi, D.M., Amah, C. (2013) "Synthesis, Characterization and Antifungal Activities of $\mathrm{Mn}$ (ii), $\mathrm{Co}(\mathrm{ii}), \mathrm{Cu}(\mathrm{ii})$, and $\mathrm{Zn}$ (ii) Mixed-Ligand Complexes Containing 1,10Phenanthroline and 2,2'-Bipyridine."RJPBCS. 4 (1): 386. ISSN: 0975-8585.

Agwara, M. O., Ndifon, P. T., Ndosiri, N. B., Paboudam, A. G., Yufanyi, D. M., and Mohamadou, A. (2010) "Synthesis, Characterization and Antimicrobial Activities of Cobalt(II), Copper(II) and Zinc(II) MixedLigand Complexes Containing 1,10Phenanthroline and 2,2'-Bipyridine"Bull. Chem. Soc. Ethiop., 24 (3): 383-389].

Agwara, M.O., Foba - Tendo, J.N., Amah, C., Yufanyi, D.M., Ndosiri, N.B., (2012) "Thermogravimetric and Antimicrobial properties of some divalent metal complexes of Hexamethylenetramine" RJPBCS 3 (3):95 - 104 ISSN : 0975-8585 
Cox, P.A. (2005) "Instant Notes Inorganic Chemistry". ( $2^{\text {nd }}$ ed.) BIOS Scientific Publishers New York, NY 10001-2299, USA. p237

Diarmiud Jeffreys (2005), "Aspirin the remarkable story of a wonder drug", By: Bloomsubry, pp.3840.

Dilip, C.S., Kumar, V. S., Venison, S.J., Potheher, I.V., Subahashini. D. R. J. (2013) "Coordination mode of bidentate lornoxicam drug with some transition metal ion: Synthesis,characterization and in vitro antimicrobial and antibreastic cancer" J. Mol. Str., 1040:192.

El-Ghamry, M.A., Saleh, A.A., Khalil, S.M.E., Mohammed, A.A. (2013) "Mono, bi- and trineuclar metal complexes derived from new benzene-1,4-bis(3-pyridine-2ylurea) ligand" Spectra, magnetic, thermal and 3D molecular modeling studies. Spectrochim. Acta A, 110:205

Greenwood, N.N. and Wade K. J. (2011) "Chemistry of Elements" American journal society. 11:30

Huang, R., A. Wallqvist, G. Covell. 2005 Anticancer metal compounds in NCI's tumor - screening database: putative mode of action. Biochemical pharmacology, 69, 1009-1039

Kaim, W.; Schwederski, B. Bioinorganic Chemistry: Inorganic Elements of Life, John Wiley and Sons: London; 1996; pp 39-262.

Xiao-Ming, C.; Bao-Hui, Y.; Xiao, C.H.; Zhi-Tao, X. J. (1996) Chem. Soc., Dalton Trans.3465.

Lever, A.B.P. (1968) "The electronic spectra of tetragonal metal complexes analysis and significance". Coord. Chem. Rev. 3 (2), 119-140.

William, K. (1991) “Organic Spectroscopy", $\left(3^{\text {rd }}\right.$ Ed.), Macmillan Education Ltd, London, 49-54, 60-75
Lee, J.D. Concise Inorganic chemistry. $4^{\text {th }}$ ed, Champman and Hall: London, 1991. PP 6071074.

Mohamed, G.G., Mahmoud, W. H., El-Dessouky, M.M.I. (2014) "Synthesis, Characterization and in vitro Biological Activity of Mixed Transition Metal Complexes of Lornoxicam with 1,10phenanthroline". Int. J. Electrochem. Sci., 9:1415 $-1438$

Philip A. Mackowiak, (2000) "Brief History of Antipyretic Therapy Clinical infection Diseases", London, pp154-156.

Puglisi, A., M. Benaglia, R. Annunziata and A. Bologna. (2003). Enantiomerically pure phenanthroline or bipyridine containing macrocycles: a new class of ligands for asymmetric catalysis. Tetrahedron Letters, 44, 2947-2951]38

Shebl, M., Seleem, H.S., El-Shetary B.A. (2010)."The ligational behavior of a phenolic quinolyl hyrazone towards copper (II) ions" Spectrochim. Acta Part A, 75:428.

Sliverstein, R.M., Bassler, G., Morrill, T. (2005) "Spectrometric Identification of organic Compounds", New York, ( $7^{\text {th }}$ Ed.), John-Wiley.

Triathi, I.P. and Aarti, K. (2014). "Synthesis and characterization of some complexes of copper(II) with L-asp arginine, L-histidine, L-lysine" American journal of advanced drug delivery, 29:2561.

Wecker H. and Laubert A., (2000) "Reversibl hearing loss in acute salicylate", New York, pp.52-65. 